\title{
The evolution of the classical ombudsman: $A$ view from the Antipodes ${ }^{\star}$
}

\author{
Professor Anita Stuhmcke, Faculty of Law, University of Technology, Sydney
}

\begin{abstract}
The traditional core functions of a classical ombudsman are the investigation of individual complaints and own motion investigations of administrative action into areas of systemic importance. The ombudsman institution is an evolving one. Classical ombudsmen are using their systemic investigation powers more frequently to improve the quality of public administration. Further, there is an increasing variety of functions, such as auditing and monitoring, which are now ascribed to the jurisdiction of ombudsmen. This article investigates the changes occurring in the scale and scope of ombudsmen functions and argues that three models of classical ombudsman may now be identified. An explanation of these models and the reasons for changes in the operation of ombudsmen are provided through the experience of the nine
\end{abstract} Australian Federal, State and Territory classical ombudsmen.

Keywords: Ombudsman, investigation, dispute resolution, complaint-handling

\section{INTRODUCTION}

The word 'ombudsman' is a powerful brand name ${ }^{1}$ used to describe a model of institution which originates from the 1809 Swedish Parliamentary Ombudsman (Riksdagens ombudsman). Today ombudsmen are both global in operation and multifaceted in nature, existing on every continent, at every level of government, across both public and private sectors. Ombudsmen are ever evolving and the expansion of the ombudsman institution is not just one of scale but is also one of scope. ${ }^{2}$ One important recent development is the changing focus of the classical ombudsman jurisdiction from primarily providing redress to individual's complaints to placing more emphasis upon systemic investigations and expanding functions to include auditing and monitoring which have the primary goal of improving the overall quality of public administration.

\footnotetext{
*An informal term often used to refer to Australia and New Zealand.

${ }^{1}$ Bingham, TC. (1972) "Ombudsman: "The Dayton Model"” 41 University of Cincinnati Law Review 807.

${ }^{2}$ Field, C. (2009) 'Recent evolutions in Australian Ombudsmen' Presentation to the Australian Institute of Administrative Law National Forum 2009,3.
} 
As Caiden states '[T]he existence of the ombudsman formally acknowledges that government though good is fallible and could be improved'. ${ }^{3}$ The aim of this article is to examine the different models of the classical ombudsman which have been developed to promote good administration. Part 2 of this article identifies three models of classical ombudsman which reflect the degree to which an ombudsman office promotes improving the quality of government administration a role which 'is being given increased priority by a number of ombudsman around the world'. ${ }^{4}$ Part 3 then explains why these differing models have developed in an Australian context. It argues that critical factors which determine the degree to which an ombudsman focuses upon the promotion of good administration across government will include: the agenda and the discretion afforded to individual ombudsman in terms of the legislative and institutional framework of its operation; the historical, political and legal environment of the jurisdiction within which the ombudsman operates; and the degree of regard within which the institution is held.

\section{MODELS OF CLASSICAL OMBUDSMAN}

\subsection{The first model: The Reactive Ombudsman Model (ROM)}

In 1974 the International Bar Association defined a classical ombudsman as:

An office provided for by the constitution or by an action of the legislature or parliament and headed by an independent, high-level public official who is responsible to the legislature or parliament, who receives complaints from aggrieved persons against government agencies, officials and employees or who acts on his own motion, and who has the power to investigate, recommend corrective action and issue reports. ${ }^{5}$

This definition captures the first model of classical ombudsman, titled 'the Reactive Ombudsman Model'. This model describes an institution having the core role of individual complaint-handling, the traditional role of most classical ombudsmen. ${ }^{6}$

\footnotetext{
${ }^{3}$ Caiden, GE. (1983) 'The Institution of the Ombudsman' International Handbook of Ombudsman: Evolution and Present Function, Greenwood Press, 4.

${ }^{4}$ Buck T, Kirkham R \& Thompson B. (2011) The Ombudsman Enterprise and Administrative Justice Ashgate, 147.

${ }^{5}$ Ombudsman Committee, International Bar Association Resolution (Vancouver: International bar Association, 1974) cited in Reif, LC (2004) The Ombudsman, Good Governance and the International Human Rights System, Martinus Nijhoff Publishers, 3.

${ }^{6}$ Hill, LB. (1976) The Model Ombudsman: Institutionalizing New Zealand's Democratic Experiment Princeton, Princeton University Press; Seneviratne, M. (2002) Ombudsman: Public Services and Administrative Justice London, Butterworths.
} 
Critically however while this model is "primarily a client-oriented office, designed to secure individual justice in the administrative state ${ }^{7}$ it also has an equally important function of being concerned to improve government decision-making. Thus, a ROM is not merely an instrument of redress, but also will have the function of quality control of government administration. The ROM therefore embeds two functions. Firstly, a reactive role of providing redress for the individual complainant and secondly, a proactive role of being concerned that administrative failures are rectified to prevent mistakes form occurring in the future.

The title 'reactive ombudsman' is therefore not intended to imply that this model has no proactive functions - rather it is used to expose the emphasis placed by such ombudsmen upon resolving disputes between government administration and the individual complainant. An ombudsman belonging to the $R O M$ will usually exercise proactive activities through using discretion to initiate own-motion investigations. Such systemic investigations aim to generate recommendations to improve procedures, policy or legislation. This role of the ROM is generally closely aligned with the individual complaint handling role:

The own motion power may be used, for example, to investigate deficiencies of a systemic character (that is, where it appears there are problems associated with an agency's practices, policies, or procedures). Such an investigation may be undertaken because a specific complaint has pointed to the possibility of some underlying systemic problem or because the receipt of a number of complaints on the same matter has suggested such a possibility. ${ }^{8}$

This proactive power therefore operates in concert with or independently from the individual complaint handling role.

Arguably to be a ROM there is no requirement that a discretionary own motion power be part of the ombudsman jurisdiction nor that it be exercise with any frequency. This is the case as the systemics role of the ombudsman institution includes any or all functions which transcend the individual complainant. At its broadest any function of the ombudsman which aims to improve the normative decision-making processes of government administration is part of its proactive role. Such functions may therefore be characterized as the recommendations and investigations which aim to improve procedures, policy or legislation. Often ombudsmen will perform the two processes simultaneously: the reactive process of individual complaint-handling being dependent on the incidence of conflict while the proactive counterpart role of making recommendations and suggesting positive change to administration as a result of the individual complaints is done on a continual basis. Looked at from this broad perspective the own motion

\footnotetext{
${ }^{7}$ Seneviratne, M. Ibid, 11.

$8 \quad$ Commonwealth Ombudsman, Annual Report (1990-91) 1.
} 
power is but one example of the proactive powers of the ROM. There may be no need to exercise an own motion investigation to improve the system more universally.

The ROM describes many international ombudsmen offices. For example Seneviratne notes its applicability to the work of ombudsman in the United Kingdom ${ }^{9}$ and in a now rather dated survey of ombudsman worldwide undertaken by Haller ${ }^{10} 41$ of the 43 ombudsman surveyed internationally said that besides individual complaint handling one of their functions was to improve administrative practices. One of the best examples of the ROM is the first modern ombudsman, the Swedish Ombudsman, which has authority to ensure that public complaints against public officials have an avenue for resolution and also has the proactive own motion powers. Another example, of a ROM which actively uses systemic investigations to pursue proactive administrative improvement is the Ontario Ombudsman office.

This dual role of the ROM - of conflict resolution and conflict prevention (to investigate individual complaints and to rectify systemic administrative failures) is echoed in judicial dicta. The clearest formulation of such support in an early common law decision on public sector or classical ombudsman is made in Alberta, Canada in 1970, Chief Justice Milvain states in Re Ombudsman Act (1970) (72 W.W.R. 176, 190 and 192):

the basic purpose of an Ombudsman is provision of a 'watchdog' designed to look into the entire workings of administrative cases. ... [he] can bring the lamp of scrutiny to otherwise dark places even over the resistance of those who would draw the blinds. If [his] scrutiny and reservations are well founded, corrective measure can be taken in due democratic process, if not no harm can be done in looking at that which is good.

In Australia all nine classical ombudsmen (one Federal Ombudsman, six State Ombudsmen and two Territory Ombudsmen) ${ }^{11}$ originally belonged to this first model of Ombudsmen. Introduced in the 1970s the focus of each office was to generally one of emphasis upon the individual complainant ${ }^{12}$ with all offices having the capacity to exercise a proactive own motion power to initiate investigations at their discretion.

\footnotetext{
${ }^{9}$ Seneviratne, Ombudsman: Public Services and Administrative Justice.

${ }^{10}$ Haller, W. (1998) 'The place of the ombudsman in the world community', Fourth international Ombudsman Conference papers, Canberra, 34-36 cited in Seneviratne, M. (1994) Ombudsmen in the public sector Open University Press, 12-13.

${ }^{11}$ The Commonwealth Ombudsman was established in 1976 by the Ombudsman Act 1976 (Cth) and all of the State Ombudsmen were also established in the 1970s: Western Australia in 1971 by the Parliamentary Commissioner Act 1971 (WA) ; South Australia in 1972 by the Ombudsman Act 1972 (SA); Victoria in 1973 by the Ombudsman Act 1973 (Vic); Queensland in 1974 by the Ombudsman Act 2001 (Qld); New South Wales in 1974 by the Ombudsman Act 1974 (NSW); Tasmania in 1978 by the Ombudsman Act 1978 (Tas); Northern Territory in 1977 by the Ombudsman (Northern Territory) Act 1977 (NT); and the Australian Capital Territory in 1983 by the Ombudsman Act 1989 (ACT).

${ }^{12}$ Pearce, D. (2005) 'The Jurisdiction of Australian Government Ombudsmen', in Groves, M. (ed.), Law and Government in Australia, Federation Press, Sydney, 110-138.
} 
This dominant emphasis placed upon the reactive individual complaint handling function was a direct result of modeling the Australian institution on existing ombudsman - particularly that of the New Zealand Ombudsman which had been appointed in 1962 under the Parliamentary Commissioner (Ombudsman) Act $1962(\mathrm{NZ})$.

\subsection{The second model: Variegated Ombudsman Model (VOM)}

Today in Australia none of the nine classical Ombudsmen may less easily be categorised as belonging to the first ROM. Instead almost all offices belong to a second model - the Variegated Ombudsman Model. This model is characterized by an increasing scale and scope in jurisdiction of classical ombudsman. While the emphasis of the institutions in this model remains upon the essential core features of an ombudsman (as described under $R O M$ ) what distinguishes this group of ombudsmen is growth in both the number and variety of functions they perform.

The Commonwealth Ombudsman is an example of a VOM. From inception, the Ombudsman Act 1976 (Cth), established the Commonwealth Ombudsman as having a core focus upon individual complaints and also as having a systemic role of suggesting reform and improvements to government administrative systems. ${ }^{13}$ Today the Commonwealth Ombudsman performs separately titled roles of Australian Capital Territory Ombudsman, Defence Force Ombudsman, Taxation Ombudsman, Immigration Ombudsman, Law Enforcement Ombudsman, Postal Industry Ombudsman and Overseas Student Ombudsman.

While significant in identifying the scope of the operations of an ombudsman, the number of titles an office may carry is itself not determinative of categorisation as belonging to the VOM. Such categorization may also depend upon the variety of functions performed by an institution. The Commonwealth Ombudsman has increasingly taken on new functions of inspecting, auditing and monitoring functions to ensure agencies comply with legislative requirements. These are 'new' function for ombudsmen. Auditing and monitoring are separated from the more traditional roles of complainthandling and system-fixing in that they imply a lack of interference by ombudsmen in agency policy and processes and instead represent a role which is one of verification and examination. They also are functions which are carried out to promote the protection of individuals - particularly vulnerable individuals such as indigenous persons and suspected illegality. Recognition of the importance of this role has been noted by Australian ombudsmen. For example, in 2004-05 the Commonwealth Ombudsman states: '[C]ompliance auditing has now developed as a distinct third function of the office, in addition to its

\footnotetext{
${ }^{13}$ Stuhmcke A. (2010) 'Each for Themselves' or 'One for All'? The Changing Emphasis of the Commonwealth Ombudsman' 3(1) Federal Law Review.
} 
traditional functions of complaint investigation and own motion investigations ${ }^{14}$ Such unique and additional roles may direct the classification of an ombudsman as belonging to the VOM.

Similarly, other Australian State and Territory ombudsman have increased the scope of their jurisdiction to extend to functions which differ from the traditional dual roles of individual complaint handler and systemic investigator. For example the Western Australian Ombudsman now has an extension of jurisdiction to investigate child deaths and telephone interception and the Western Australian Ombudsman, like the Tasmanian Ombudsman, performs a private industry ombudsman role - both offices being the Energy Ombudsman for gas and electricity. This practice of classical ombudsman performing separate roles of complaint handling for private industry and non-traditional government areas is now echoed across most Australia jurisdictions (the exception may be the South Australian ombudsman which could be categorised as ROM although the South Australian ombudsman notes it will commence a program of 'systemic audits' from 2010-2011 ${ }^{15}$ ). So, for example, the Northern Territory Ombudsman is also the Commissioner for Health and Community Services Complaints.

Another example of the classification of a classical ombudsman as a VOM is the grant of an additional legislative human rights role. On 1 January 2007, the Victorian Government through the Victorian Charter of Human Rights and Responsibilities Act 2006 conferred an express human rights mandate upon the Victorian Ombudsman. When examined from a human rights perspective this explicit conferral of human rights legislative powers created the first sub-national human rights or hybrid ombudsman ${ }^{16}$ in Australia. From a human rights perspective the Victorian Ombudsman thus joins the 50 per cent of the worlds ombudsman institutions which may be categorised as human rights ombudsman. ${ }^{17}$ When viewed from a classical ombudsman perspective the Victorian Ombudsman is belongs to the VOM, having an explicit mandate to protect and promote human rights of individuals. This addition of an express human rights mandate marks a new focus for an Australian State classical ombudsman with respect to ensuring that administrative decision-making with respect to the delivery of government services is carried out in accordance with human rights principles.

Of course there is growing recognition amongst all Australian ombudsmen that their work has a human rights focus. Such awareness and the degree to which it impacts upon the work of an ombudsman may variously categorise an office as a ROM or a VOM. For example the operation of the Human Rights Act 2004 was noted by the Australian Capital Territory Ombudsman: ${ }^{18}$

\footnotetext{
${ }^{14}$ Commonwealth Ombudsman, Annual Report (2004-05) 1.

15. South Australian Ombudsman Annual Report (2009-2010) 5.

${ }^{16}$ Reif, The Ombudsman, Good Governance and the International Human Rights System,2-11, 393.

${ }^{17}$ Ibid.

${ }^{18}$ ACT Ombudsman, Annual Report (2009-2010) 29.
} 
The Ombudsman's office also plays an important role in human rights protection. The right to complain is both a right in itself, implicit in the civil and political rights listed in the Human Rights Act, and one of the best mechanisms to ensure that all other rights can be protected. It establishes a fundamental status for the individual in his or her dealings with government. The existence of public sector ombudsmen and other such bodies is crucial to minimising the inequality of power, resources and information that can prevent this right, and those available through it, from being exercised.

Another identifier of the VOM may be the degree to which the Ombudsman performs a role in educating government agencies to improve standards of complaint handling. So, for example, the Queensland Ombudsman states on its website that: 'As part of our ongoing commitment to improve public sector administrative practice, we offer training to State government agencies and local councils across Queensland in the following areas:

- Good Decisions Training

- Complaints Management Training

- $\quad$ Ethical Decision Making Training

Such educative functions locate an ombudsman office outside of the $R O M$ as it signifies a formal role in participating in educational reform across government departments and agencies. This function may also include making submissions to government inquiries with respect to law reform and the publication of newsletters and E-Bulletins on improving administrative practice to government departments. ${ }^{19}$

Significantly these educative functions may be part of a wider concept of community engagement where a VOM may perceive its role as informing and protecting the wider community. This community engagement function as pursued by a VOM has an activist flavor. For example, again returning to the Queensland Ombudsman reference is made in the 2009-2010 Annual Report to: ${ }^{20}$

The Office's first public report on an investigation was published in Parliament in May 2002. The 'Brooke Brennan' report - An investigation into the adequacy of the actions of certain government agencies in relation to the safety of the late Brooke Brennan, aged three - was tabled in Parliament on 31 May 2002. The report succeeded in raising public awareness of major deficiencies in the operation of the child protection system in Queensland and led to

\footnotetext{
${ }^{19}$ For example the Commonwealth Ombudsman has published reports with indicative titles-Issues Relating to Oral Advice: Clients Beware, 1997; A Good Practice Guide for Effective Complaint Handling, 1999; and Report on Investigation of Administration of FOI in Commonwealth Agencies, 1999.

${ }^{20}$ Queensland Ombudsman, Annual Report (2009-2010), 19.
} 
some significant improvements in the system, including a better process for reviewing child deaths.

Such engagement is targeted not only at public awareness of the work of the ombudsman but to educate the public to become activists for government change and thereby improving administrative processes.

Finally, it is important to note that despite the plethora of roles, the changes to jurisdiction and an increased focus on the quality of public administration, a VOM retains the individual complainant as its primary focus. As stated in the most recent Commonwealth Ombudsman Annual Report: ${ }^{21}$

One of the primary functions of the Ombudsman's office is to handle complaints and enquiries from members of the public about government administrative action. The aim is to promote fairness and accountability by fostering integrity and legislative compliance in agency administration.

\subsection{The third model: Proactive Ombudsman Model (POM)}

There is no 'requirement' that an ombudsman exhibit a duality of roles of being both a system fixer and a change agent in order to be titled 'ombudsman'. To take both extremes this means that an ombudsman may be solely an individual complaint handler, and conversely, may be wholly a systemic reformer. In actuality most ombudsman lie somewhere between those two end points and this is why most classical ombudsman will fall into ROM or VOM. There is also no need for the two roles to conflict however as Seneviratne notes 'decisions have to be made about which functions should take precedence'. ${ }^{22}$ It is where such a conscious decision has been made to primarily pursue the proactive function that an ombudsman will be part of the Proactive Ombudsman Model (POM).

In Australia the NSW Ombudsman is an example of the POM. As Mr Bruce Barbour, the current NSW Ombudsman in a recent speech to the International Ombudsman Institute World Conference in Stockholm states: ${ }^{23}$

We need to accept that change will happen, and we need to be the driver of this change, to look for better and more effective ways to operate, to re-shape the Ombudsman model to keep pace with community needs and expectations, to explore and question - to see as possible what we have previously thought was not. This will be essential if we are to remain

\footnotetext{
${ }^{21}$ Commonwealth Ombudsman, Annual Report (2009-2010) 2.

${ }^{22}$ Seneviratne, Ombudsmen: Public Services and Administrative Justice, 17.

${ }^{23}$ Barbour, B. (2009) 'Actions speak louder than words: An Ombudsman's office and children' IOI World Conference Stockholm.
} 
relevant. Thinking this way has taken my office into very different decision making practices, thinking carefully about where we place our focus and the way we prioritise and undertake our work. We have evolved from a reactive complaint handling body into a forward-thinking, strategic, community focussed and proactive office. Using the core principles of our Swedish heritage, building on them, developing them to meet the needs and circumstances of our own community. Placing them in today's context and planning for tomorrow.

While a large number of Australian ombudsmen - in particular the Commonwealth Ombudsman and the Queensland Ombudsman - are increasingly giving emphasis to prioritising proactive standard-setting roles rather than the traditional role of reactive complaint-handling only the NSW Ombudsman states that it promotes its proactive roles over its reactive complaint handling role. The New South Wales Ombudsman actively restricts the number of individual complaints taken in order to focus upon its system fixing role of improving administrative justice. ${ }^{24}$ For example, the NSW Ombudsman fact sheet which contains information for individuals complaining about government agencies, states that '[W]e do not have the resources to investigate every complaint, so priority is given to serious matters, especially if it is an issue that is likely to affect other people. If we cannot take up your complaint we will tell you why. ${ }^{25}$ Further, in the 2009-2010 Annual Report the NSW Ombudsman states the significance of its proactive work: ${ }^{26}$

We help organisations to prevent or reduce the level of complaints made about them by reviewing their systems. Our proactive work also allows us to address problems if members of the public have legitimate grievances but, for whatever reason, do not or cannot take up the complaint themselves. We aim to reduce the volume of complaints to our office by providing training and advice to the organisations we scrutinise about how to effectively resolve and manage complaints. We also provide assistance, guidance and training to other watchdog agencies.

Both the Commonwealth Ombudsman and the Queensland Ombudsman hover between being a VOM and a $P O M$ - see for example the comments by the recently retired Ombudsman Mr David Bevan in the where he refers to the complaint handling and improving administration role as being a 'blend of functions' which 'makes our Office such an effective catalyst for positive change in the public sector'. ${ }^{27}$ The NSW Ombudsman however is clearly part of the VOM.

Critically in terms of the goals and operation of the VOM the NSW Ombudsman still regards individual complainants as significant. It is however the scope of the non-individual complaint handling and non-

${ }^{24}$ NSW Ombudsman, Annual Report (2005-2006) 1.

${ }^{25}$ Reproduced in NSW Ombudsman, Annual Report (2009-2010) 173.

${ }^{26}$ Ibid 1.

${ }^{27}$ Queensland Ombudsman, Annual Report, (2009-2010) 15. 
own motion systemic investigations work which categorises the NSW Ombudsman as being part of the VOM. The jurisdiction of the NSW Ombudsman extends beyond traditional government agencies to focus increasingly upon the type of service delivered. As the NSW Ombudsman Annual Report 2009-2010 states: ${ }^{28}$

We are responsible for keeping the following types of organisations under scrutiny:

- $\quad$ agencies delivering public services - including police, correctional centres and state-owned corporations

- $\quad$ organisations delivering services to children - including schools and child care centres

- $\quad$ organisations delivering community services - including services for people with disabilities, people who are homeless and elderly people

- $\quad$ agencies conducting covert operations - including the Crime Commission and the Independent Commission Against Corruption.

We have other specific functions that relate to:

- $\quad$ the causes and patterns of deaths of certain children and people with disabilities

- decisions made by public sector agencies

- the administration of the witness protection program

- the implementation of new pieces of legislation conferring additional powers on people such as police and correctional officers.

Apart from the scope of the work the scale is also of significance for classification as a VOM. For example, with respect to community engagement and education, the distinguishing feature between the NSW Ombudsman and ombudsmen that fall within the VOM is the size of the operations of the Office. In 20092010 the NSW Ombudsman:

- Undertook more than 271 information, community education and training activities reaching over 10,237 people, including providing 144 training workshops. ${ }^{29}$

- Hosted three community forums (one of which was attended by 300 people) on domestic violence, probity and the devolution of large institutions; ${ }^{30}$

- Initiated a roundtable forum of government agencies to examine the various screening processes that funded services use when checking for information about the probity of prospective employees, board or management committee members and other volunteers involved in the planning or delivery of community services - the roundtable resulted in a report containing recommendations for reform submitted to government under section 31 of the Ombudsman Act $1974 .^{31}$

\footnotetext{
${ }^{28}$ NSW Ombudsman, Annual Report (2009-2010) Introduction.

${ }^{29}$ Ibid 41.

${ }^{30}$ Ibid 28.

${ }^{31}$ Full report available at:

http://www.ombo.nsw.gov.au/publication/PDF/specialreport/SR_ImprovingProbityStandards_Dec10.pdf
} 
It is however the scope of the multifaceted functions of the NSW Ombudsman that render it a POM rather than the role that the Office plays in agitation for change. As Mr Barbour states:

While our work may lead to legislative or policy changes, this is not our primary aim or goal.

Our role is to act in the public interest, to ensure the lawful exercise of powers, good administrative practice and fair and transparent decision making. ${ }^{32}$

Central to the categorization of the NSW Ombudsman as a VOM is the view the office has that it can play a role in shaping, protecting and promoting community expectations.

Importantly the NSW Ombudsman does not view itself as an advocate for the community or for government. Indeed in this sense the NSW Ombudsman remains faithful to its Swedish heritage and the shared grundnorm of Ombudsman. Rather than being an advocate the NSW Ombudsman is a VOM due to the scope of its operations across the whole of government. Indeed viewed from this perspective the individual complaint handling role of the NSW Ombudsman remains critical and is afforded due tribute as such by the office. As stated in the 2009-2010 Annual Report (which celebrates 35 years of the NSW Ombudsman): ${ }^{33}$

In our first year, we received complaints about 138 different public authorities. This year, we dealt with complaints about almost 1,000 agencies and organisations. These included both public and private sector bodies, providing a broad range of services. This number may well increase with future changes to our jurisdiction.

The scope and extent of the NSW Ombudsman proactive operations rather than any change in core values which renders the Office part of the $P O M$.

\section{WHY AN INCREASING DIVERSITY OF CLASSICAL OMBUDSMAN MODELS?}

There are three main reasons which explain the identification of three models of classical ombudsman in Australia:

Firstly, ombudsmen adapt to fit their jurisdiction. As a Federation each Australian level of government - State, Federal and Territory - had its own unique requirements and the model introduced in every jurisdiction was a deliberate and considered choice. The Australian ombudsmen model was from the

${ }^{32}$ Barbour, B. (2010) Speech, NSW Ombudsman: Speech - The Ombudsman and Civil Liberties, 2.

${ }^{33}$ NSW Ombudsman, Annual Report (2009-2010) 111. 
very beginning, one which was adapted to the Australian system of government. The shared history of Australian ombudsmen should not mask the reality which is a diversity of function and operation as every Australian government calibrated ombudsmen for its own political environment. The introduction and development of each of the nine ombudsman offices in Australia is therefore idiosyncratic. Indeed, this is reflective more generally of the transplantation and adaptation of the institution to suit varied political, economic and social requirements has occurred since the first transportation of ombudsman. For example, writing in 1970 Barrie $^{34}$ observes the significant jurisdictional differences between the first four classical ombudsman introduced outside of Sweden - Finland (1919), Denmark (1954), Norway (1962) and New Zealand (1962):

Finland, for example, has paid special attention to inmates of institutions where people are involuntarily restrained. In Sweden great importance has been placed on the control of inferior judicial tribunals. In New Zealand and Denmark provision has been made for complaints emanating from civil servants about employment conditions, promotion and discipline.

It follows that just as the creation of an ombudsman will suit the political environment within which it operates so will each individual office adapt to changes within that environment.

The identification of three models of Australian classical ombudsmen originates from the mid1990s, coinciding with the changing way that government delivers services. The privatization and corporatization of previously government run monopolies such as telecommunications, gas, water and electricity not only introduced new complexities into complaint resolution handling but also resulted in the creation of new complaint handling bodies such as private industry ombudsman. The creation of such bodies has meant that Australian ombudsman have had to maintain their relevance and carve out a niche for themselves in an ever growing landscape of integrity bodies which govern disputes between citizen and the state and the consumer and industry .

To illustrate this point further - a clear ramification of this external change is a growth in classical ombudsman jurisdiction to cover previously private sector services. For example the Commonwealth Ombudsman now has an explicit jurisdiction to investigate complaints against government service providers, defined as a non-government entity that is providing goods or services to the public under a contract with a government agency (Ombudsman Act s 3BA (CTH)). This extended jurisdiction is important in enabling efficient investigation of complaints about immigration detention, which is managed by a private company, and against non-government organisations that play a pivotal role in assisting job

34 Barrie, GN (1970) 'The Ombudsman: Governor of the Government' 87 South African Law Journal 238. 
seekers and benefit claimants as part of the Welfare to Work and Job Network programs. ${ }^{35}$ Also the Commonwealth Ombudsman in its Postal Industry Ombudsman role can deal with complaints against both Australia Post (a government business enterprise) and private postal operators that register with the scheme.

Secondly, for an office to expand its functions there must be a willingness from the Ombudsman to take the additional powers on. Of course how an office is managed is very much a matter of the personal style and working methods of the incumbent Ombudsman. ${ }^{36}$ Professor John McMillan, the previous Commonwealth Ombudsman, noted one of his reasons for taking on new powers being that:

A perennial concern of Ombudsman offices is their meagre funding, especially as contrasted to the growth in size and functions of the government agencies the Ombudsman oversights. History indicates that Ombudsman offices do not get extra funding and support from government by bleating about their restricted funding. On the other hand, recent developments illustrate that Ombudsman offices will be given extra funding by government if they can demonstrate their ability and effectiveness in discharging new functions. Indeed, a strong theme in contemporary budgetary policy around Australia is that government agencies face annual efficiency dividends that can reduce their core funding, but this can be countered by acquiring a new function that attracts additional funding. The adoption of new functions has been the key to the doubling in size of my own office in recent years. ${ }^{37}$

On a slightly different note the significance of the input of Ombudsman is critical as a change in focus of an office does not have to be driven by legislative jurisdictional change, rather may be implemented by the use of discretion by ombudsman A sharper focus on own motion investigations and a decreasing importance placed upon individual complainants may significantly alter the role of an office and the emphasis it places upon improving the quality of government administration.

Thirdly, the growth of Ombudsman functions reflects acceptance and trust of the institution within Australian jurisdictions. Ombudsmen are efficient, free and offer access to justice widely accepted as an alternative pathway to the resolution of disputes outside of the judicial system. This coincides with a growing appreciation in Australia of the usefulness of Assisted Dispute Resolution techniques. ${ }^{38}$ Australian ombudsmen are now entrenched as independent, impartial and fair dispute resolution offices. Their role in preserving and upholding the rule of law is widely acknowledged. Trust in the institution in terms of both

\footnotetext{
${ }^{35}$ McMillan, J. (2008) 'The expanding role of the Ombudsman: What fits? What doesn't?' available at www.ombudsman.gov.au.

36 Commonwealth Ombudsman, Annual Report (1980-81) 56.

${ }^{37}$ McMillan 'The expanding role of the Ombudsman'.

${ }^{38}$ Field, C. (2009) 'Recent evolutions in Australian Ombudsmen' Presentation to the Australian Institute of Administrative Law National Forum 3.
} 
its permanency in the legal and political landscape and its ability to deliver results has been a direct contributor to an institution which has increased in scale and scope.

\section{CONCLUSION}

Internationally classical ombudsmen are increasing the scope of their jurisdiction so that today an ombudsman may perform any or all of the functions of: individual complaint handler; human rights protector; own motion investigator (proactive systemic change agent or system fixer); auditor; protector of whistleblowers; reviewer of witness protection; reviewing child abuse and reportable deaths; educator; community change agent etc. Such multifaceted functions render the allocation of ombudsman into the traditional models of classical ombudsman increasingly strained. Such traditional models include: the 'redress and control' model ${ }^{39}$ division along the lines of function such as into three models - basic or classical model, the rule of law model and human rights model ${ }^{40}$ and the firewatching and firefighting model. $^{41}$

Classical ombudsmen are increasingly heterogeneous - a fact which Kuckso-Stadlmayer notes conflicts with the classification of ombudsman offices into models. ${ }^{42}$ Indeed Buck et al observe that ' $[\mathrm{I}] \mathrm{t}$ would be a mistake, however, to understand all ombudsman schemes as neatly fitting into any standard fixed and predictable model of ombudsmanry'. ${ }^{43}$ Somewhat paradoxically however it is this very diversity together with the shared universal characteristics of ombudsman which facilitate ombudsman being grouped into models and subsets of models. Indeed the classical ombudsman is today broadly acknowledged to be augmented by the model of the human rights ombudsmen ${ }^{44}$ and of the private industry ombudsmen. ${ }^{45}$ Further, within each of these ombudsman models, sub-groups have been identified. So, for example Tai identifies six models of human rights ombudsmen ${ }^{46}$ and Reif identifies 10 different variations of public sector and private sector ombudsman mechanisms. ${ }^{47}$

\footnotetext{
${ }^{39}$ Heede, K. (2002) European Ombudsman: redress and control at Union level Kluwer Law International $79-112$

${ }^{40}$ Kuckso-Stadlmayer G (ed), (2008) European Ombudsman-Institutions Springer Wien New York, 61-65.

${ }^{41}$ Harlow, C \& Rawlings R. (1997) Law and Administration.

${ }^{42}$ Kuckso-Stadlmayer, European Ombudsman-InstitutionsSpringer Wien New York, 59.

${ }^{43}$ Buck et al, The Ombudsman Enterprise and Administrative Justice 224.

${ }^{44}$ Reif,LC. (2000) 'Building Democratic Institutions: The Role of National Human Rights Institutions in Good Governance and Human Rights Protection' 13 Harvard Human Rights Journal 23.

${ }^{45}$ Seneviratne, Ombudsmen: Public Services and Administrative Justice.

${ }^{46}$ Tai, BYT. (2010) ‘Models of Ombudsmen and Human Rights Protection' 1(1.3) International Journal of Politics and Good Governance 1.

${ }^{47}$ Reif, The Ombudsman, Good Governance and the International Human Rights System, 26-28.
} 
The adoption of a particular model of classical ombudsman will depend upon institutional, cultural and personal factors. The longevity of an ombudsman institution may both result in, and be brought about by, adaptation and calibration of functions - in short, classical ombudsman adapt to changed operational environments. The increased heterogeneous nature of the classical ombudsman must therefore be viewed against the backdrop of shared fundamental norms of the ombudsman model. While classical ombudsman may place differing emphasis upon the handling of individual complaints or the improvement of public administration the institution will continue to adapt and be successful if it adheres to the basic precepts of ombudsmanry such as independence, impartiality and maintenance of the rule of law. The identification of the three models of classical ombudsmen in this article confirms both the adaptability of the evolving nature of the ombudsman institution and demonstrates how it will continue to maintain its relevance. The ombudsman institution, now almost four decades old in Australia, has proven to be both nimble and responsive to external events while remaining intact with respect to its core features. 